\title{
ПАТРІОТИЗМ ЯК КОНЦЕПТ СУЧАСНИХ МЕДІАТЕКСТІВ
}

\author{
Лариса Писаренко \\ Національний університет «Одеська юридична академія» \\ вул. Академічна 7б, 65009, Одеса, Україна \\ e-mail: pisarenko0906@gmail.com \\ https://orcid.org/0000-0003-1905-823X
}

У статті досліджується поняття «концепт» 3 погляду лінгвістики, культурології та психології; детально вивчаються медіатексти, в яких реалізується концепт «патріотизм»; окреслено значущість теми патріотизму та патріотичного виховання в контексті суспільно-політичних подій в Україні. 3'ясовано, що «патріотизм»- багатогранний, аксіологічний концепт, який реалізується у різних смислових значеннях, знаходить своє вираження у темах патріотичного спрямування та органічно співвідноситься з ментально-психологічними ознаками українського народу, його традиціями, віруваннями, культурою, свідомістю, уявленнями, почуттями, безперечно, мовою.

Ключові слова: концепт, патріотизм, медіатекст, виховання, Україна.

Актуальність дослідження. Тема патріотизму в Україні на сьогодні $є$ дуже важливою у зв'язку з подіями на сході України, інформаційною війною між Україною і Росією. Патріотизм - це поняття дуже широке, і в рамках тільки цього дослідження повністю ми не зможемо його розкрити. Але на часі гостро постає проблема патріотичного виховання дітей та молоді. Це, в свою чергу, змушує як викладачів, так і вчителів шкіл по-новому підійти до визначення даного поняття, до усвідомлення ролі патріотичного виховання у житті кожного підлітка, пересічного студента.

Мета - дослідити «патріотизм» як концепт сучасних медіатекстів на матеріалі газети «Народна армія» (офіційний сайт Міністерства оборони України - 2014, 2015, 2018, 2019 - вибірково).

Завдання - проаналізувати поняття «концепт» 3 точки зору лінгвістики, культурології та психолінгвістики; детально вивчити медіатексти, в яких реалізується концепт «патріотизм»; окреслити значущість теми патріотизму та патріотичного виховання в контексті суспільно-політичних подій в Україні.

Виклад основного матеріалу. Перш ніж проаналізувати концепт «патріотизм», необхідно визначитись 3 тим, що таке «концепт» взагалі. 3 цього приводу існує безліч точок зору, але у своїй роботі ми звертаємось до філософської й лінгвістичної.

У «Новітньому філософському словнику» подається таке визначення концепту (лат. conceptus - поняття) - зміст поняття, його смислове наповнення в абстрагуванні від конкретно-мовної форми його вираження, що актуалізує відображену в понятті

(C) Писаренко Л., 2019 
онтологічну складову цього поняття» [7: 503]._Це поняття першими використовували філософи, а саме: Е. Гуссерль, Х.-Г. Гадамер, М. Гайдеггер, Хосе Ортега-і-Гассет, 3. Фрейд, Т. Юнг та інші.

Саме уявлення про «концепт» як складову свідомості зародилося в Давній Гре-

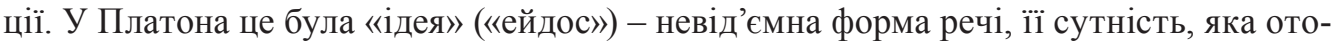
тожнюється з буттям. Пізнання сутності стає можливим завдяки мові, яка в античності розглядалася як сукупність імен, за допомогою яких людина узагальнює й систематизує світ, виявляє свою причетність до спільноти, робить себе об'єктом для інших і для самої себе.

Щодо філософських концепцій середньовічного концептуалізму Т. Гоббса, П. Абеляра, то концепт - це універсалія, яка завдяки абстрагуючій діяльності інтелекту об'єднує в один клас схожі ознаки одиничних речей і називає їх одним іменем. За П. Абеляром концептом є сукупність понятійного й духовного сенсу, що синтезує в собі минуле (функція пам'яті), теперішнє (функція судження) і майбутнє (функція уяви) за умови визначальної сили розуму. Переведення «поняття в певну категорію мислення чи мовлення відбувається в момент мовленнєвого акту, в результаті чого «повний смисл слова» визначається одночасно понятійним вираженням і контекстом мовлення, що робить процес формування смислу зумовленим культурно-історичними, ідеологічними, психологічними уявленнями певного часу [1: 88-89].

У системі лінгвістичного вчення В. фон Гумбольдта проблема кодування й інтерпретації смислу у процесі породження й сприйняття мовлення постає у зв’язку з «внутрішньою формою мови», під якою він розуміє спосіб зв'язку думки зі звуком [3: 71], у результаті чого словесний знак набуває особливої природи, перетворюючись у символ певної понятійної єдності [3:127-128].

На думку О. О. Селіванової, Н. В. Бардіної концепт є психоментальне утворення, функція якого - збереження та перетворення в індивідуальній свідомості інформації про світ і самого індивіда. О. О. Селіванова прирівнює концепт до ментально-психонетичного комплексу, що містить пропозиційну структуру істинних об'єктивних знань (рівні диктуму), їхню суб’єктивну оцінку (модус), асоціативно-термінальний компонент неістинної, зокрема метафоричної інформації, сформований на основі зв'язків диктуму з іншими ментально-психонетичними комплексами, а також численні реакції з психічними функціями: відчуттями, почуттями, інтуїцією, образами тощо [9: 114].

3 точки зору Н. В. Бардіної, концепт є «цілісний комплекс, який включає в себе не тільки чистий смисл, але й зв'язані з ним прояви ментальності (стереотипів думки, волі й емоцій)» [2: 10].

На думку українського лінгвіста А. Приходько, існує декілька дефініційних моделей концепту: 1) концепт як епістемічне утворення, що грунтується на усвідомленні інформаційних витоків знань і досвіду людини; 2) концепт як психоментальне утворення, зумовлене розумінням концепту як продукту людської свідомості; 3) концепт як етнокультурне утворення, що відображає уявлення про концепт як концентроване вираження духовно-емоційного досвіду певного етносу, згусток культури; 4) концепт як прагмарегулятивне утворення, що відображає інтенційний характер використання ментальних сутностей у дискурсі; 5) концепт як аксіологічне утворення, що є результатом ціннісних домінант культури; 6) синтетичну дефініцію концепту, що містить поєднання кількох аспектів [8: 46-48]. 
Основними дискусійними проблемами, пов’язаними з кваліфікацією феномена концепту, О. О. Селіванова вважає 1) розмежування концепту й поняття; 2) залежність концепту від мовної вербалізації; 3) його кваліфікація за способами формування; 4) зв’язок концепту та значення; 5) наявність у структурі концепту оцінно-емотивних, ціннісних і прагматичних компонентів; 6) наявність концептів в індивідуальній або колективній (загальнонаціональній, груповій, регіональній) свідомості; 7) обсяг концепту залежно від індивідуальної чи етнічно-колективної репрезентації, наукової чи наївної картини світу; 8) типологія концептів; 9) їхня структура; 10) методи та процедури опису й аналізу концептів тощо [10:].

Що ж до визначення концепту «патріотизм», то він має багато різних визначень, які розкривають його різноплановість. В українському суспільстві «патріотизм» - це багатоаспектне явище. У кожного з нас воно викликає різні почуття. Більшість словників дають визначення «патріотизму» як любові до Батьківщини. Так, в Академічному тлумачному словнику української мови «патріотизм» - це любов до своєї Батьківщини, відданість своєму народові, готовність для них на жертви й подвиги [11: 97].

У Філософському енциклопедичному словнику «патріотизм» (від грецьк. патpia - вітчизна) - любов до Батьківщини, відповідальність за її долю і готовність служити iii iнтересам, а в разі потреби самовіддано боронити здобутки свого народу; соціально-політичний і моральний принцип, що в загальній формі виражає вищеназвані почуття та емоційні стани. Патріотизм як соціально-психологічне почуття має широку гаму проявів: від гордості за досягнення Вітчизни (в науці, економічній діяльності, спорті і т.д.), поваги до історичного минулого, дбайливого ставлення до народної пам'яті, збереження та опанування національними і культурними традиціями до гіркоти переживань за невдачі і втрати рідної країни, страждань через її біди [14: 471].

У Словнику соціологічних і політологічних термінів «патріотизм»- почуття любові до Батьківщини, ідея, свідомість громадянської відповідальності за долю вітчизни, що виражається у прагненні служити своєму народові, захищати його інтереси [12: 90].

Ми поставили за мету розглянути концепт «патріотизм»у таких аспектах, як історичний, соціальний і психологічний, а потім простежити, як же він репрезентується в сучасних медіатекстах. Ми погоджуємося з позицією Н. І. Череповської, яка характеризувала «патріотизм» через призму історії, соціології та психології. Так-от, якщо розглядати «патріотизм» з точки зору історичної, то тут слід звернути увагу на любов до рідного краю або території. Бо споконвіку людина обирала собі місце проживання (тобто територію, на якій вона могла б займатися землеробством і передавати свою землю у спадок нащадкам). Також до територіальних ознак Н. І. Череповська віднесла «конституційний патріотизм» - коли люди пишаються досягненнями своєї країни (наприклад, українці пишаються розбудовою вільної, демократичної держави; «державний патріотизм» - любов до України, гордість за неї, за її досягнення; «регіональний патріотизм» - любов людей до свого регіону як батьківщини, місця, де народився і проживає твій рід; «помісний патріотизм»- любов до свого міста; «екологічний патріотизм» - бережливе ставлення до рідної природи, збереження ресурсів своєї країни; «побутовий патріотизм» - любов до рідної домівки, оселі, вулиці, подвір'я тощо [13: 10]. 
Якщо розглядати соціальний аспект «патріотизму», то тут, на нашу думку, слід звернути увагу на ставлення людей до інших етнічних груп, народів, до їхніх традицій, вірувань, культури, а також до того, наскільки людина може бути вірною своїй спільноті. Саме в такому ставленні один до одного ми виділяємо поняття «свій чужий», «друг - ворог». У цьому контексті Н. І. Череповська виділила «загальнонаціональний патріотизм» - на сьогодні в Україні цей вид патріотизму є актуальним і включає в себе толерантне ставлення до всіх громадян України. Також сюди авторка відносить «етнопатріотизм», який розуміється як любов до свого етносу або народу [13: 11].

Що ж стосується психологічного аспекту, то він подає концепт «патріотизм» як комплекс суб'єктивних почуттів до Батьківщини, які є значущими для кожної окремо взятої особистості. На нашу думку, серед патріотичних почуттів окремої особистості можна виділити переконання, світогляд, цінності, готовність до практичних дій за свою Батьківщини, які мають продовжуватися у її поведінці, вчинках. Цікавим $з$ цього приводу є обгрунтування Н. І. Череповської, яка виділила такі форми індивідуальних, особистісних «патріотизмів»:

- «ура!-патріотизм» - заснований лише на гіпертрофованих почуттях, які «здіймаються» легко, як піна: ці почуття зазвичай поверхові, хоча й стенічні; він може бути дієвим, але, як правило, неконструктивним; сутність: сильні, але нетривалі почуття;

- «піднесений псевдопатріотизм», здебільшого неконструктивний; «українофільство» - щира любов до всього українського: культури, традицій, мови; колекціонування предметів ужитку, народного одягу; участь у культурних заходах; мовлення виключно українською, часто вишуканою, мовою; носіння вишиванок і т. ін., але на користь Батьківщини майже або зовсім нічого не робиться;

- «будьмо-гейний!» (від гасла: «Будьмо! Гей!») - так званий «застільний» патріотизм, який актуалізується у формі гасел, емоцій (як правило, під час застілля); недієва форма; «галушковий» - так само форма поверхового патріотизму, що виражається в любові до національної кухні (галушок, вареників, борщу), у культивуванні деяких продуктів, наприклад, сала тощо; недієва форма;

- «зітхальний» / «сентиментальний» - також заснований на неконструктивних емоціях, зумовлених, наприклад, заглибленням в історію України, яку «без брому читати неможливо!», ознайомленням з художньою літературою, що відображає героїчну, військово-патріотичну тематику, або переглядом повідомлень iз зони АТО, про неоднозначне політичне життя країни, висвітлених в медіа; така інформація сприймається переважно драматично, зі сльозами, зітханнями; у контексті сучасних подій у країні - додатково доповнюється депресивними настроями, песимістичними висловами («усе пропало!», «знову зрада!», «усе погано!»); бездіяльний, пасивний вид патріотизму; властивий сентиментальним, боязким людям;

- «ідеалістичний» - виявляє ставлення особистості, їі любов саме до ідеального образу Батьківщини, якої ще не існує або яку спотворює «неправильна» влада; утім, їі ідеальні обриси омріяні в літературних творах, або збережені в прадавніх міфах, легендах;

- «громадянський», або «конструктивний», - любов до Батьківщини поєднується із сумлінним ставленням передусім до своїх персональних конституційних, 
правових, професійних обов'язків (навчання), а також із суспільно корисною діяльністю через громадянську активність; утілюється в результатах, що в цілому мають сприяти розвиткові рідної країни; дієвий патріотизм, акцент - на конструктивній дієвості;

- «військовий» - забезпечується військово-патріотичним вихованням і складанням присяги професійними військовими вірно служити своїй Батьківщині, своєму народові i, якщо треба, віддати за це своє життя; активний, конструктивний тією мірою, яка передбачена специфікою самої військової діяльності; дієвий патріотизм, акцент - на професійній готовності захищати територіальну цілісність країни, свій народ і психологічній готовності загинути за Батьківщину;

- «ідейний / жертовний» - передбачає безмежну самовідданість суб'єкта ідеї служіння Батьківщині (або націоналістичній ідеологіï), готовність повністю поступитися особистими інтересами і присвятити їй своє життя, терпіти муки і навіть пожертвувати власним життям заради України. Так, повстанці Холодного Яру боролися за самостійну Україну, а їхнім гаслом було «Воля України або смерть!»; націоналісти ОУН і вояки УПА сповідували ідею створення УССД: «Здобудеш Українську (самостійну, соборну) державу або загинеш за неї в бою!»;

- патріотизм героїв Майдану, перших добровольців АТО, патріотів ЗСУ об'єднує ідея: «Україна - понад усе!», в якій закладено намір змінювати країну на краще, захищати її територію від ворогів, навіть ціною власного життя. Це - найвища, жертовна любов до Батьківщини; дієвий патріотизм, акцент - на готовності до самопожертви, високого чину (вчинку) [13: 13-14].

Проаналізувавши тексти газети «Народна армія», ми прийшли до висновку, що концепт «патріотизм» у даних текстах виражається в різних формах:

- «військовий» - «патріотизм», що проявляється «в сучасних боєздатних та інноваційних ВМС України, які спроможні захистити національні інтереси держави з морського напрямку» [6: 08.02.2019].

- «ідейний» - «...професіоналізм, патріотизм, відповідальність. Саме такою має бути політика Міністерства оборони. Саме такою позицією щодо кадрового забезпечення Збройних сил повинен керуватись весь командний склад нашої армії...» [6: 26.03.2014].

- «патріотизм» як комплекс суб’єктивних почуттів до Батьківщини - «...його патріотизм заряджав та надихав, а любов та повага до державних символів завжди була прикладом до наслідування» [6:02.2019].

- «ідейний» - «це віковічне прагнення українців бути вільними і незалежними. І сьогодні українські військовослужбовці гідно захищають свою землю, доводячи всім, що жодна армія нічого не варта без справжніх патріотів, героїв, готових на самопожертву у боротьбі за незалежність і територіальну цілісність України». [6: 13.07.2015].

- «державний патріотизм» - «...формування в особового складу патріотизму як однієї з найвищих духовних цінностей, що проявляється у самовідданій любові громадянина до своєї Батьківщини, усвідомленій потребі та прагненні зміцнювати і захищати її» [6: 26.06.2018]

- «громадянський» - «...організація обласних, міських, районних заходів 3 метою утвердження патріотизму, духовності, моральності та формування загальнолюдських цінностей молоді...» [6: 27.11.2015]. 
- «конструктивний» - «... треба сіяти зерня патріотизму. Адже зараз воюють діти, які народилися за часів початку незалежності України. Вони мали б знати що таке патріотизм, національна гордість...» [6: 27.11.2015].

- «соціальний» - «...об'єднання у творчому процесі сприяє зміцненню єдності, зростанню патріотизму та національного духу в Україні, єднанню всіх навколо любові до рідного слова, рідної землі, - підкреслив Юрій Работін» [6: 22.08.2015].

Висновки. Аналіз медіатекстів газети «Народна армія» дає можливість констатувати, що «патріотизм» - це поняття багатогранне, це аксіологічний концепт, який реалізується у різних смислових значеннях, знаходить своє вираження у темах патріотичного спрямування та органічно співвідноситься 3 ментально-психологічними ознаками українського народу, його традиціями, віруваннями, культурою, свідомістю, уявленнями, почуттями, безперечно, мовою.

Перспективи подалыших досліджень. У подальшому маємо на меті поглиблено вивчити концепт «патріотизм». Провести соціологічне дослідження серед студентів факультету журналістики, опрацювати окремо тексти, в яких розкриваються вищевказані аспекти, не тільки у газетно-журнальних матеріалах, а й у кіномистецтві, на радіо і т. ін. Сподіваємося, ця тема знайде своє вираження у працях сучасних психолінгвістів, соціологів, філологів.

\section{REFERENCES}

1. Абеляр П. Теологические трактаты / П. Абеляр; [составл., коммент., вводн. ст. С. С. Неретиной; пер. с лат. С. С. Неретиной]. М. : Прогресс - Гнозис, 1995. 413 с. (Философская школа).

2. Бардина Н. В. Античная матрица нашей души: [монография] / Н. В. Бардина. Одесса: Астропринт, 2009. 288 с.

3. Гумбольдт В. Избранные труды по языкознанию / Перевод с нем. языка и с предисловием Рамишвили Г. В. / В. Гумбольдт. М. : Прогресс, 1984. 397 с.

4. Концепція національно-патріотичного виховання молоді. Додаток до наказу Міністерства освіти і науки України від 16. 06. 2015 р. № 641

5. Наказ Міністра оборони України від 08.06.2010 року № 295 «Про затвердження Концепції військово-патріотичного виховання у Збройних Силах України».

6. «Народна армія». Офіційний веб-сайт Міністерства оборони України.

7. Новейший философский словарь / сост. и гл. н. ред. А. А. Грицанов. 3-е изд., 2003).

8. Приходько А.М. Концепти і концептосистеми в когнітивно-дискурсивній парадигмі лінгвістики / А.М. Приходько. Запоріжжя : Прем’єр, 2008. 332 с.

9. Селиванова Е. А. Когнитивная ономасиология (монография) / Е. А. Селиванова. К. : Изд-во Украинского фитосоциологического центра, 2000. 248 с.

10. Селіванова О.О. Світ свідомості в мові. Мир сознания в языке : [монографічне видання] / О.О. Селіванова. Черкаси : Ю. Чабаненко, 2012.

11. Словник української мови: в 11 томах. Том 6, 1975. С. 97.

12. Словник соціологічних і політологічних термінів / Нар. укр. акад.; за заг. ред.: В. І. Астахової [та ін.] ; уклад. В. І. Астахова [та ін.]. Київ: Вища шк., 1993. 140 с.

13. Череповська Н. І. Медіаосвітні ресурси розвитку патріотизму і критичного мислення молоді : навчально-методичний посібник / Н. І. Череповська; Національна 
академія педагогічних наук України, Інститут соціальної та політичної психології. Кропивницький : Імекс-ЛТД, 2017. 156 с.

14. Філософський енциклопедичний словник : энциклопедия / НАН України, Ін-т філософії ім. Г. С. Сковороди ; голов. ред. В. І. Шинкарук. Київ : Абрис, 2002. 742 с.

\title{
PATRIOTISM AS A CONCEPT IN MODERN MEDIA TEXTS
}

\author{
Larysa Pysarenko \\ National University «Odesa Law Academy» \\ 7-b, Akademicheskaya street, 65009, Odesa, Ukraine \\ e-mail: pisarenko0906@gmail.com \\ https://orcid.org/0000-0003-1905-823X
}

This article explores the idea of «concept» in terms of linguistics, cultural studies and psycholinguistics; media text are studied in detail, in which concept is realied; outlined the significance theme of patriotism and patriotic education in context of socio -political events in Ukraine. It has been found out that «patriotism» is a multifaceted, polyfunctional, axiological concept and that is realized in various semantic values, is expressed in themes of patriotic orientation, but is holistic and organically tangent to mental-psychological features of Ukrainian nation, to its traditions, beliefs, culture, consciousness, ideas, feelings, undoubtedly language.

In this article, we have assessed the concept of «patriotism» in historical, social and psychological aspects and investigated the way it is represented in modern media texts.

Having assessed «patriotism» from a historical point of view, we have identified people's expression of love for their home country or territory, seeing how people choose their own place of living, that is to say, a territory, suited for farming, which can be passed on to the descendents.

Regarding the social aspect of «patriotism», we have noticed people's attitude towards other ethnic groups, peoples and their traditions, beliefs, culture as well as the ability to stay true to your community. These communal attitudes are what defines the concepts of «our» versus «strange» and «friend» versus «enemy».

As for the psychological aspect, «patriotism» is being interpreted as a range of subjective feelings about one's homeland, which are significant for each given individual. Among patriotic feelings one may distinguish beliefs, convictions, worldview, values and being committed to you homeland's prosperity, which shows in one's behaviour and actions.

Key words: concept, patriotism, media texts, education, Ukraine. 